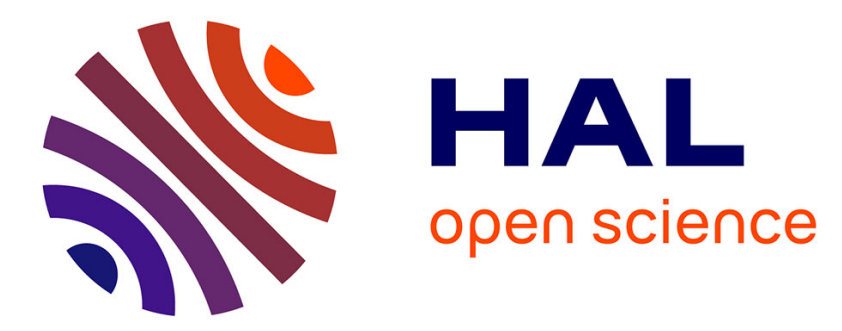

\title{
Current developments in police governance and accountability in Ireland
}

Vicky Conway, Dermot P. J. Walsh

\section{To cite this version:}

Vicky Conway, Dermot P. J. Walsh. Current developments in police governance and accountability in Ireland. Crime, Law and Social Change, 2011, 55 (2-3), pp.241-257. 10.1007/s10611-011-9271-z . hal-00668058

\section{HAL Id: hal-00668058 https://hal.science/hal-00668058}

Submitted on 9 Feb 2012

HAL is a multi-disciplinary open access archive for the deposit and dissemination of scientific research documents, whether they are published or not. The documents may come from teaching and research institutions in France or abroad, or from public or private research centers.
L'archive ouverte pluridisciplinaire HAL, est destinée au dépôt et à la diffusion de documents scientifiques de niveau recherche, publiés ou non, émanant des établissements d'enseignement et de recherche français ou étrangers, des laboratoires publics ou privés. 


\section{Current Developments in Police Governance and Accountability in Ireland}

\section{Vicky Conway and Dermot P.J. Walsh*}

\section{Abstract}

2005 saw the passing of landmark legislation for policing in Ireland - the Garda Siochána Act - which made substantial changes to the structures and operation of governance and accountability. It came on the heels of the greatest scandal ever faced by the Irish police. This paper sets out to assess critically the impact of that legislation. We begin by considering the nature of police reform and the various conditions necessary for successful change. We then contextualise the reforms in Ireland, considering the existing structures of governance and accountability and highlighting the numerous concerns which existed in relation to them. The focus then turns to the Morris Tribunal, which documented gross misconduct and corruption in one Garda division. We examine how this served as a major catalyst for reform in Ireland. The paper then turns to consider the reforms themselves providing an overview of the legislation and critiquing in depth a number of features: the clear centralisation of government control over the police, the limited independence of the new independent police complaints body and the failure to fully embed the reforms in a human rights agenda. We conclude by arguing that insufficient steps have been taken to address police governance and accountability in Ireland and that the best opportunity for such reform may have been missed.

\section{Introduction}

That scandal can have a reformative capacity for policing organisations is neither unusual nor undesirable. In jurisdictions across the world, the swift action taken following the 'heat' of a scandal has been well documented: the Scarman Report into the Brixton riots led to the introduction of the Police and Criminal Evidence Act 1984 in England; the Mollen Commission in New York in the 1990s resulted in an overhaul of the internal affairs division, changes in training, and increased monitoring of police for corrupt activities; and in New South Wales, the Wood Commission resulted in a fundamental reform of policing[12]. Practice and theory has demonstrated, however, that it is easy in such pressurised and intense situations to implement programmes of reform which either fail to address the core problems which caused the scandal in the first place, or which

Vicky Conway, Lecturer in Law, Queen's University Belfast, Dermot Walsh, Professor of Law, University of Limerick. 
address the scandal but ignore other flaws in the system [36, 40,6]. Reforms become targeted at individual officers under the bad apples thesis, ${ }^{1}$ or at one policing unit, believed to be inherently susceptible to corruption. Organisational and institutional defects go unchecked.

In this paper, we examine this reform post-scandal process in the Irish context, where, over the past decade, the most substantial inquiry into policing since the creation of the police force, has exposed and documented corruption, abuse and negligence (the Morris Tribunal of Inquiry). The government and the force acted swiftly, implementing a detailed package of reform. ${ }^{2}$ In this paper we aim to assess critically the extent to which this programme will address problems within the Irish police force. Beginning with an overview of the international literature on police reform, we proceed to outline the context of policing in Ireland at the time of the inquiry. The reforms implemented by the government will then be analysed focusing on three aspects: police complaints, centralisation of governance and human rights developments. Finally, we will conclude, drawing on the international experience and literature, that these reforms will be insufficient to prevent future outbreaks of misconduct and corruption.

\section{Police Reform}

A variety of factors can instigate police reform. Stenning and Shearing [44] differentiate primarily between factors which are internal and external to the police force:

- Internal: efficiency, service not force, community policing/ intelligence led policing/ evidence based policy/ reassurance policing, changes in police officer demographics, competition from private policing and scandals.

- External: states in transition, move to human rights, best practice policing (globalisation/harmonisation), population booms/demographic changes, changing concepts of justice/move to restorative justice.

\footnotetext{
${ }^{1}$ Stoddard [45; p.201] has defined the bad apples thesis as premised on the belief "that unlawful activity by police is a manifestation of personal moral weakness, a symptom of personality defects, or a result of recruitment of individuals unqualified for police work". Newburn [36] has noted how it is invariably relied upon where a scandal has occurred but that the evidence, in most cases, proves otherwise. In New York the Knapp Commission dismissed claims by senior New York police management that the corruption in that instance was down to a few bad apples. Knapp declared that this position, which was borderline 'official doctrine', was an 'obstacle to meaningful reform'. ${ }^{2}$ In this chapter we focus on the reform implemented by the government. For a discussion of the reform implemented internal to the police see Fitzgerald [13], Conway [10] and Walsh [51].
} 
The nature of the driver will impact on the nature of the reform. For instance, questions around efficiency and a desire to have a service rather than a force will often lead to the implementation of managerialist reforms [41], while a state in transition, often attempting to leave a previously undemocratic system behind, may pay much greater attention to human rights concerns [37]. Where scandals are involved in prompting reform we may find that the reforms will be 'knee-jerk' and reactionary in nature, with little pause for reflection $[43,39,36]$. They will be directly targeted at the ills identified as being the cause and in need of remedying, though again with little reflection the target is unlikely to be accurately identified. Of course, as authors such as Newburn [36] and Punch [39] have repeatedly demonstrated, police misconduct which occurs on a scale which merits the label 'scandal' is invariably the result of attitudes and approaches to policing which are interwoven and embedded in the police culture. It is also a clear sign that internal and external oversight and governance mechanisms, however they exist, have failed. In spite of that, a common response, both from government and senior police management, is that the misconduct or corruption is in fact the result of a few bad apples and not in anyway institutionalised [45]. This is a destructive response which will be damaging for police morale and ignore the realities of problems at supervisory and management levels [36, 39].

Punch has stated that in response to reform the following should occur: an energetic cleanup campaign; strong leadership; more powerful internal investigative capacity; enforcement of measures against police deviance either through internal disciplinary methods or criminal prosecutions, and a fundamental overhaul of the organisation, involving changes in personnel at all levels [39]. We would develop this further to emphasise a need to reflect on the accountability and governance of the organisation. In doing this, as was done so directly in Northern Ireland by the Patten Commission [38], and focusing on creating a system tied to central values of transparency, democracy, human rights and public consultation, the harm caused to public confidence by the scandal can be repaired, while at the same time most effectively ensuring that further scandal can be prevented. Recognising that no such thing as a 'perfect' system can be created, particularly where we are concerned with an evolving organisation (rolling personnel, changing regulatory powers) which operates within an evolving society, we further adopt the position exposed by others such as Newburn [36] and Chan [6] that reform should not be seen as a moment but a continual process. It is from this standpoint 
that we now turn to consider reform of accountability and governance in Ireland in the past few years.

\section{Background}

Prior to gaining its independence in 1922, Ireland was policed by two heavily centralised, government controlled constabularies: the Dublin Metropolitan Police [22] for Dublin and the Royal Irish Constabulary (RIC) in the rest of the country $[28,1]$. During the fight for independence these forces had been heavily attacked, viewed as emblematic of British power in the country. ${ }^{3}$ They were replaced soon after independence, and from 1925 onwards the country has been policed by a single national force: the Garda Síochána. ${ }^{4}$

In many respects the Garda Síochána was modelled on its RIC predecessor. ${ }^{5}$ It was a national force; it was composed of a hierarchical pyramid of military style ranks with a Commissioner at the apex [48: p.15]. The Commissioner was directly answerable to the Minister for Justice, with no external involvement in governance. The force as a whole was under the tight control of the central government which enjoyed the power of hire and fire, not just over the Commissioner, but also over the ranks down to and including middle management level. The Department of Justice also exercised close control over the force on a day to day basis. There was no local or community or independent oversight of the force. ${ }^{6}$ Complaints, if there were any, were to be dealt with internally. ${ }^{7}$

Important differences from the RIC were that the Garda Síochána was generally unarmed $^{8}$ and it served a directly elected government, rather than a despotic government,

\footnotetext{
${ }^{3}$ According to Lowe [24] in 1920/21 there were over 10,000 attacks on the RIC with 355 officers killed in that period.

${ }^{4}$ Meaning Guardians of the Peace. A member singular is called a garda and the plural is gardaí. The force was formally created by the Police Force Amalgamation Act 1925 which amalgamated the DMP, which had continued to exist until this time, and the Civic Guard / Garda Siochana, which had been created in 1922 to replace the RIC. For a history of the force see Allen [1], McNiff [28], Brady [4] and Breathnach [5].

${ }^{5}$ This was quite a deliberate decision as many of those involved in deciding on the new force believed that until the national unrest, the force had operated well in the country. Further, the Police Organisation Committee was given just three weeks to plan for the new force making it difficult to deviate substantially, see Allen [1].

${ }^{6}$ The need to make the force accountable is apparent in many speeches by the first Minister for Justice, Kevin O'Higgins, however, as the government was tasked at that point with building the full institutions, structures and laws for the State, this was not an issue perceived as taking priority. ${ }^{7}$ S.18 of the Police Forces Amalgamation Act allowed for the Commissioner to establish an inquiry to investigate 'any charge or complaint of neglect or violation of duty'.

${ }^{8}$ The Civic Guard as established in 1922 had in fact been an armed force but following a mutiny of recruits in Kildare Barracks an inquiry was held and recommended that the force be unarmed. See Allen [1]. Members of the Special Branch continue to be armed.
} 
based in Dublin castle. ${ }^{9}$ Michael Staines, the first Commissioner of the force, declared that the force would 'succeed not by force of arms but on its moral authority as servants of the people.' There was also a close identity and bond between gardaí and the community. One of the first Commissioners of the force, Eoin O'Duffy, worked hard to create a police force which was emblematic of the Irishness which, it was claimed, British rule had oppressed [27]. To this end, members of the new force were pioneers, spoke and taught Irish, excelled at Irish sports and were devoutly religious, going on pilgrimages to Rome and Lourdes. Indeed, Allen asserts that it was the suppression of the distillation of poitín, which had become widespread and destructive of communities during the Civil War period, that enamoured the new force to the public in the first instance [1]. This was despite the fact that it was also the State's security service, the eyes and ears of the political establishment. Unlike other jurisdictions there was no division between the State functions of policing and security. In the newly formed State, which was opposed and overtly challenged by many who had contested the creation of the border with Northern Ireland, the Special Branch was an important and active division. ${ }^{10}$

From 1925 up until at least the 1970s there was virtually no change in the status, structures, management, values, policies or practices of the Garda Síochána. The Conroy Commission of 1970 introduced substantial changes on matters such as pay and working conditions [7], ${ }^{11}$ following serious unrest within the force, ${ }^{12}$ but there were no changes introduced which related to governance or accountability. It was as if the force was frozen in time; much of the $20^{\text {th }}$ century just seemed to pass it by. On the other hand, it also managed to escape any serious crisis in public confidence. With the outbreak of the Troubles in Northern Ireland in 1969 and the consequent overspill of crime and subversive activity into the Republic, resulting in the deaths of a number of gardai in the 1970 s and 80 s, the first since the 1930s, the force resumed the position of guardians and

\footnotetext{
${ }^{9}$ Indeed, officers of the RIC were often referred to 'the Castle's men', in reference to Dublin Castle, where the British administration in Ireland was based.

${ }^{10}$ Breathnach [5] discusses allegations of abuse of detainees by Special Branch men and how at times in the 1930s they were not welcome in certain parts of the country.

${ }^{11}$ The Conroy Commission introduced over-time payments for the first time, introduced a 42 hour working week, deemed some stations as 'not fit to live in', as well as recommendations on recruitment, training, accommodation and discipline. The changes brought about in the wake of Conroy have been described by McNiff [28] as 'herald[ing] a new era'.

${ }^{12}$ In the late 1960s nearly 1000 officers participated in go-slow protests, and gathered in the Macushla Ballroom, attending a meeting which had been banned by the Commissioner, to express their dissatisfaction at pay and working conditions. It culminated in the dismissal of 11 leaders who were only reinstated after the intervention of the Arch-Bishop of Dublin.
} 
defenders of the State. ${ }^{13}$ They effectively became untouchable in terms of criticism. While there were occasional controversial incidents and practices, most notably allegations of a 'Heavy Gang' using force to extract information and confessions from IRA suspects in the late $1970 \mathrm{~s},{ }^{14}$ it was the $1980 \mathrm{~s}$ before it was finally accepted that there was a need for independent oversight of the handling of citizen complaints against gardaí; and even then the model introduced was a very mild one.

The Garda Siochana Complaints Board was created largely in response to two events. In 1984, in what became known as the Kerry Babies Case, a young woman and her family gave false, detailed confessions to the murder of a new born baby. This was the subject of an investigation by a Tribunal of Inquiry which failed to attach any significant blame to the gardaí involved [25]. That same year the Criminal Justice Act gave gardaí a general power of arrest without charge. Significant opposition to this increase in Garda powers was only assuaged by the promise that the powers would only be brought into force in conjunction with an independent mechanism for the investigation of complaints against gardaí. The "independent" Complaints Board which ensued was composed of the Garda Commissioner (or his nominee) and government appointees. It relied on gardaí to conduct investigations on foot of complaints made by members of the public, but had the power to establish tribunals to adjudicate on possible breaches of the disciplinary code disclosed by such investigations. The lack of real independent investigation, compounded by serious under-resourcing which caused the Board to cease work on occasion, made for a gravely inadequate system. ${ }^{15}$ The Board itself called for its replacement with a more independent body on numerous occasions and it was the subject of intense criticisms from NGO's, academics and civil liberties groups [48].

The picture changed dramatically throughout the 1990s, as the force was hit with a steady stream of allegations, which increasingly challenged its benign image and raised serious

\footnotetext{
${ }^{13}$ As one Minister for Justice stated: "There is nothing between us and the dark night of terrorism but that Force. While people in this House and people in the media may have freedom to criticise, the Government of the day should not criticise the Garda Síochána" (Noonan, Dáil Eireann, 10 November 1987).

${ }^{14}$ The existence of the gang has always been denied by Garda management and the Department of Justice, but was exposed by the Irish Times in February 1977 who documented accounts of prisoners who had been subjected to torturous interrogation techniques. "Gardaí using North-style brutality in Interrogation Techniques" (14 February 1977), "Beaten by Six Guards" (14 February 1977), "Heavy Gang used New Act to Intensify Pressure on Suspects" (15 February 1977), "Claustrophobia Victim says Gardaí Shut Him in Locker" (16 February, 1977).

${ }^{15}$ Irish Times, 16 December 1989.
} 
public concerns of a breakdown in discipline. Numerous convictions were overturned following evidence of Garda misconduct in the gathering of evidence. ${ }^{16}$ Interviews with suspects were not routinely recorded until the beginning of the twenty-first century [46]. The use of force by Irish police officers was repeatedly documented by the European Committee for the Prevention of Torture (CPT) on visits in 1993, 1998 and 2003. It has been the subject of more inquiries and investigations over the past ten years than it experienced over its previous 80 year history. Simultaneous to the emergence of allegations investigated by the Morris inquiry, a Tribunal of Inquiry was appointed to investigate the shooting dead of John Carty, a man suffering from serious mental illness, at a barricade incident in Abbeylara in April 2000 [2]. The Tribunal Chairman, Mr. Justice Barr, found that the scene was poorly managed and operational decisions were not properly made. On May Day 2002, the Garda handling of a street protest in Dublin resulted in the prosecution of seven gardaí for assault on protestors [15; p.11]. In 2005, Hugh Hartnett SC was appointed to conduct an inquiry into the death of Brian Rossiter, a 14-year-old who died following time in Garda custody [21]. In May 2005 a Commission was established to investigate how Dean Lyons, a homeless heroin addict, who was considered borderline mentally handicapped, could have made a false confession to murder while in Garda custody [3]. The most significant and damaging of these inquiries was the Morris Tribunal.

\section{The Morris Tribunal}

Richard Barron was injured on a roadside in Donegal in October 1996 and died later in hospital [30]. Initially it was suspected to be a 'hit and run' incident, however, local gardaí soon decided, on the basis of rumour and false witness statements, and without a state autopsy, that two men, Frank McBrearty Jnr and Mark McConnell, had murdered him [30; para. 1.07]. Six weeks later, a dozen people from their two families were arrested in connection with the investigations. Dozens of complaints ensued about their treatment in custody. They alleged that a campaign of harassment had been mounted against them. Over one hundred prosecutions were brought against the McBrearty family in the coming years.

\footnotetext{
${ }^{16}$ See the cases of Peter Pringle, Damien, Marsh, Vincent Connell, Fred Flannery, Dean Lyons, Nora Wall, Frank Shortt, and, perhaps most contentiously, Paul Ward who had been convicted in relation to the murder of journalist of Veronica Guerin.
} 
In early 1999, while these prosecutions were still making their way through the courts, questions began to appear in the media and in the Dáil (the lower House of the Irish Parliament) about Garda methods in Donegal, ${ }^{17}$ including allegations which went beyond the handling of Mr Barron's death. The Minister for Justice indicated that Assistant Commissioner Carty was conducting an internal investigation. This extended to allegations that gardaí had planted fake IRA bomb finds on both sides of the border for the purposes of self-promotion. The opposition parties in Parliament repeatedly pushed the Minister to establish a Tribunal, but this was resisted. ${ }^{18}$ In November 2001 an opposition motion to set up a Tribunal resulted in the closest vote in the history of that government. ${ }^{19}$ Eventually in March 2002, almost five and a half years after Mr Barron died, the establishment of the Tribunal was announced. The terms of reference, however, excluded Garda Headquarters, the Department of Justice and the Minister for Justice from its remit. ${ }^{20}$

The Tribunal, chaired by Justice Frederick Morris, former President of the High Court, began work in July 2002 and over the next six years, heard over 600 witnesses, and produced 8 reports totalling over 4,000 pages. The reports provide the most frank, balanced and critical account of policing in Ireland written by a judicial figure. The findings in each report are highly damning of the Gardaí, at both rank and file and senior level.

In his first report Justice Morris found that two officers used a woman, whom they pretended was a member of the IRA, to plant fake bombs/bullets/weaponry at locations on both sides of the border on at least six occasions [29]. Senior officers were heavily to blame for failing to investigate the status of this woman: had they done so it would have been clear that she was not a genuine informer and their deception would have been uncovered [29; para 1.430]. Their supervision of the use of informants and of the investigation of bomb finds was found to be woefully inadequate. Where some officers tried to raise concerns, there was nowhere for them to turn. The promotion of unsuitable

\footnotetext{
${ }^{17}$ See for instance T. Brady, 'Hoax bomb among claims against Gardaí in probe' The Independent, 16 April 1999, Deputy Jim Higgins, Dáil Éireann, 05 May 1999, Vol. 504 Col. 156; Higgins, 12 October 1999, Vol. 509, Col. 24; O’Shea, 12 October 1999, Vol. 509, Col. 153; Stagg, 23 November 1999, Vol 511, Col. 579; Higgins, 16 December 1999, Vol. 512, Col. 1973.

${ }^{18}$ Jim Higgins, Dáil Éireann 07 March 2000, Vol. 515 Col. 1326

${ }^{19}$ Deputies Shatter and Howlin 20 November 2001, Vol. 544 Col. 581

${ }^{20}$ Dáil Éireann, 28 March 2002,Vol. 551, Col. 926
} 
officers was heavily criticised [29; para 1.43]. Revealing how embedded the 'blue wall of silence' was in the Garda, many of the officers in question told the Tribunal a 'tissue of lies' [29; para 6.32]. Indeed, one officer infamously stated under questioning that, 'you don't hang your own'. This wall would dog the tribunal at every stage of its investigations.

In his second report Justice Morris found that following Mr Barron's death local gardaí had failed to attend the scene promptly (in one case because they were in the pub while on duty) [30; para 3.53], failed to preserve the scene [30; para 3.122], failed to conduct an autopsy [30; para 4.31], were blinded by tunnel vision [30; para 3.165], secured a false witness [30; para 1.32], made extortion phone calls [30; para 6.86], unlawfully arrested a dozen people nearly all of whom were abused in custody [33]. The decision to arrest and charge members of the McBrearty family for murder was based on rumour and false witnesses. Those arrested suffered abuse of both a physical and mental nature, involving pushing, name calling, sensory deprivation, and the showing of Mr Barron's autopsy photographs [33; para 3.144]. A false confession was secured in one interview [33; para 7.390], and in another a fake confession was shown to a detainee [33; para 4.183]. Over a period of years following the investigation, gardaí mounted a campaign of harassment against the families involved. The McBrearty's pub and nightclub received disproportionate law enforcement attention from the local gardaí [34; para 9.37]. Drugs were planted on one family member [34; para 7.121]. Morris described the investigation of Mr Barron's death as 'corrupt in its leadership ... prejudiced, tendentious and utterly negligent in the highest degree.' [30; para 1.40] At the time of the establishment of the Tribunal the data on computer systems was amended so that the McBreartys were no longer listed as suspects in the case; but those affected were not informed of this decision. It remains unknown who killed Mr Barron, although the Tribunal has confirmed that he died by a 'hit-and-run' incident, and not murder.

In his third report, Morris found that gardaí had conspired to set up a licensing violation in McBrearty's pub and nightclub. It also found that a member of the family was falsely accused of threatening a witness by delivering a letter which contained a silver bullet [33]. This allegation had been made at the behest of officers involved in the Barron investigation. False expenses for court appearances were paid to the civilian witness in 
the subsequent proceedings, and this was later blamed on a dead officer; a matter which was described by Morris J as 'disgraceful' [33; para 2.171].

The fourth report dealt with an incident in which a fake bomb was planted on a telecommunications mast to secure arrests of local people who had been involved in protests against the erection of the mast [32]. The Tribunal suspected that this bomb had been planted by the officer who found it, and who tampered with the substances within the bomb, by conducting tests on it when it should have been submitted to the appropriate labs for forensic testing [32; para 1.41]. The next report focused on how a weapon was dangerously planted on a traveller campsite for the purpose of securing arrests for an unconnected case [31; para 3.147]. The warrants for the search which located the weapon were, the Tribunal held, either handed blank to an officer or completed after the fact [31; para 3.100]. When suspicions arose over this incident, other officers offered a false alibi for the officer considered to be responsible for planting the weapon [31; conclusions]. The travellers arrested as part of the operation made allegations of ill-treatment in Garda custody. The Tribunal found that officers made derogatory remarks about their background [31; conclusions].

The Tribunal was also tasked with examining the response of the Garda Complaints Board to complaints made by the McBrearty family [35; para 11.104]. Justice Morris found that the mechanism was completely inadequate to deal with the complaints emanating from the Donegal division both for resource and procedural reasons. While it had made the best decisions possible in the circumstances it was simply not equipped to deal with the scale of the problems. Procedurally, the Tribunal was critical of the fact that the investigating officer for the Board, a senior garda, was empowered only to collect statements from witnesses, and not to question them on any inconsistencies arising.

While no concluding report was published by the Tribunal, a number of factors which contributed to its findings emerge to indicate that the problems identified are institutionalised within an Garda Síochána [10]. Justice Morris emphasised throughout the reports that none of these events could have occurred without the negligence of superiors. The blue wall of silence was endemic, hampering Justice Morris at every stage of his investigations, epitomised by the statement of Garda Leonard: 'You don't hang your own' [29; para 1.49]. Particularly disconcerting was the finding that none of this 
could be viewed as limited to Donegal [30; para 6.02]. The Tribunal concluded that there was no reason to suspect this was the case, that all officers were trained in the same way. Problems in promotion and transfer of officers were of serious concern as was the relationship between the Department of Justice and Garda Headquarters.

\section{The Garda Síochána Act 2005}

While the Morris Tribunal was sitting, the government proceeded with the first overhaul of the legislative framework for police governance and accountability in Ireland since the 1920s. No doubt, this was at least partly a response to the concerns that led to the establishment of the Tribunal and its ongoing revelations. Requirements under the Good Friday Agreement to harmonise police accountability frameworks North and South of the border, international human rights obligations and the growing international trend towards civilian investigations of complaints against the police were also influential. The new framework was given legal force by the Garda Síochána Act 2005, which was enacted following the publication of just two of the reports of the Morris Tribunal.

From an accountability perspective the most attractive features of the Act are a reform of the complaints procedure (considered in detail below); the establishment of a Garda Inspectorate with the task of inspecting aspects of the operation of the force to ensure the efficient use of resources; and the introduction of local police-community consultation committees 'to serve as a forum for consultations, discussion and recommendations on matters affecting the policing of the local administrative authority area' [14; s.36]. Further features formalise existing practice. These include requirements on the Commissioner: to submit an annual report to the Minister [14; s.46]; to report to the government on any aspect of policing [14; ss.40 and 41]; and to keep the Minister advised on any significant developments likely to affect the preservation of public peace and order, the life and security of persons in the State, the security of the State or public confidence in the Garda [14; s.41]. The Act also empowers the Minister to appoint a person to inquire into any aspect of the administration, process or procedure of the Garda where he believes public concern exists [14; s. 42]. This is in addition to the investigatory powers of the Inspectorate and the Ombudsman Commission.

The Act modernises Garda governance, but it has done so in a manner which has concentrated police power in the hands of central government [50]. On the one hand, the 
Act gives greater budgetary autonomy to the Commissioner, but it goes on to complement that by retaining the pre-existing controls and supplementing them with an array of controls and obligations that were previously missing from the legislation. So, for example, the Minister has been conferred with a power to issue binding directives to the police commissioner concerning any matter relating to the Garda Síochána [14; s.25]. The Commissioner is also under a duty to account fully to the Government and the Minister, through the Secretary General of the Department of Justice, for any aspect of his functions [14; s.40]. This includes a duty to produce Garda records and reports. Potentially, this could be used very effectively to deliver real accountability by cutting through Garda obstructionism. Equally, however, it could be used to inflict grave damage in the form of partisan political interference in the administration of criminal justice [51]. In addition, the Act also formally confers the Minister with powers to determine and revise priorities and targets for the force, and to direct the contents of Garda Strategy Statements and Annual Policing Plans [14; s. 20]. In practice, the Minister has been exercising such powers for some years without explicit statutory authority. The Act also confirms the status of the force as a civilian police service and the State's security service. $^{21}$

The combined effect of these provisions is to render the Commissioner explicitly and unmistakeably subordinate to the Minister for Justice and/or the government on all aspects of the management of the force and in the contents of policing policies, methods and operations [50]. They lay the basis for the national police force being used as a tool of the central political establishment. The potential impact of a politicised police force has been witnessed abroad. The policing of the miner's strike in England in the 1980s, for instance, where the police enforced the policy of the government, rather than investigating crime and defending the human rights of citizens, had severe negative consequences for the confidence of the public in the police and the notion of policing by consent [42]. This danger could have been offset in the 2005 Act by the establishment of an independent policing board or police authority as a buffer between the government and the force - such as that in Northern Ireland. Unfortunately, the opportunity was not taken. The retention of the security service within the police force is similarly problematic.

${ }^{21} \mathrm{~S} .7$ of the Act identifies clearly the functions of the force which are to preserve peace and public order, to protect life and property, to vindicate the human rights of individuals, protect the security of the State, to prevent crime, bringing criminals to justice and ensuring road safety. 
Further, Justice Morris had specifically recommended that the relationship between the Department and Garda Headquarters needed to be revised so as to enhance the levels of trust between them. Since then, however, there has been a marked deterioration in the relationship between some sections of the force and government. In particular, the Minister for Justice cancelled his attendance at the 2010 Annual Conference of the Garda Representative Association when he learned that the outgoing President of the Association intended launching an unprecedented political attack on the government in his address. The text accused the government of national sabotage and treachery. It also said that gardaí and other public sector workers had endured an "unrelenting, distasteful and vitriolic attack from the Government and their wealthy cronies" during the past year. The Minister, in turn, described the speech as "an unprecedented political intervention" by a Garda representative "which have no place in a modern democracy". He went on to say that they "besmirch the long-held excellent reputation that An Garda Síochána has earned for serving the people and political institutions of this State without fear or favour. No democrat could tolerate such political interventions by any member of a police force." He also said that "the force is ill-served by such political interventions. In the light of these facts, it is impossible for me to attend the GRA conference". The new arrangements under the 2005 Act are unlikely to engender trust in such an environment.

Probably the most innovative and exciting initiative in the Act is the establishment of an independent three person Ombudsman Commission which has extensive police powers to conduct its own investigations into alleged wrongdoing by gardaí. Replacing the much criticised Complaints Board this body represents an overhaul of the accountability of the police as regards complaints from the public.

\section{Garda Síochána Ombudsman Commission}

On paper the Garda Síochána Ombudsman Commission (GSOC) has the potential to bring substantial independence to the investigation of police complaints in Ireland, with legislative provision for all complaints against the police to be independently investigated [11]. It is a three-person body, with a staff of close to 100 , which includes retired police officers from other jurisdictions and a number of gardaí on secondment to the office. It began receiving complaints in May 2007 and to date has received twice as many 
complaints on an annual basis as its predecessor. ${ }^{22}$ There may be numerous reasons for this growth but the results of GSOC's public survey, which found that $82 \%$ of people believed the new system is independent, suggest that this growth can be attributed to greater public confidence in the independence of the system [18; p.30]. This is a finding replicated in other jurisdictions: complaints in the police in England and Wales, and Northern Ireland rose at similar rates following the establishment of the Independent Police Complaints Commission and the Office of Police Ombudsman for Northern Ireland respectively.

The procedure established by the 2005 Act enables the Commission to refer a complaint to informal resolution/mediation where it is less serious [14; s.90], return it to the Garda Síochána for an investigation which may or may not be supervised [14; s.94], or it can conduct two types of investigation itself, the form depending on whether [14; s.95] or not [14; s.98] the complaint appears to involve an offence. Where it appears to involve an offence GSOC officers have similar powers to a police office, including arrest, detention, interrogation and the taking of samples, which can be used in respect of both police officers and members of the public. Following any of these investigations GSOC makes recommendations to the Commissioner on disciplinary action or, if appropriate, submits a file to the DPP.

The figures for the first two years indicate how GSOC have to date been using their powers: ${ }^{23}$

\begin{tabular}{|c|c|}
\hline Status & Complaints \\
\hline Inadmissible & $34.6 \%$ \\
\hline Admissible: & $65.4 \%$ \\
\hline $\begin{array}{c}\text { S90 Informal } \\
\text { Resolution }\end{array}$ & $14 \%$ \\
\hline S.94 Supervised & $8 \%$ \\
\hline S.94 Unsupervised & $37 \%$ \\
\hline S.95 & $0.2 \%$ \\
\hline S.98 & 40.5 \\
\hline
\end{tabular}

\footnotetext{
${ }^{22}$ This figures are combined from the Annual Reports published in 2008 [16] and 2009 [17] as well as caseload data published on the GSOC website available at http://www.gardaombudsman.ie/gsoc-gardaombudsman-CaseThroughput-March2010.htm

${ }^{23}$ As above.
} 
The first note-worthy point of these figures is the level of complaints being deemed inadmissible. While some of this will be accounted for by failure to submit a complaint within a given time or the complainant not being a person eligible to complain, the majority are deemed inadmissible because the substance of the complaint does not qualify under the Act. Complaints must relate to either suspected criminal behaviour or suspected breaches of the disciplinary code. In this, GSOC remains unchanged from the Complaints Board. Walsh argued over ten years ago for a new set of criteria to be introduced, as the disciplinary code was not designed with public concerns in mind [48; p.242,8]. That a third of the complaints from members of the public who feel sufficiently aggrieved to make a formal complaint are being rejected is unlikely to enhance the confidence of the public in the police, which is a stated aim of GSOC according to the legislation [14; s.67].

Most disconcertingly in the context of GSOC being proffered as a new, independent body, these figures reveal that $45 \%$ of cases continue to be investigated by gardaí. GSOC has focused its independent investigations on complaints appearing to involve criminal matters. If it is the case that resources are restricted, then this may be an understandable approach but it does not alter the fact that nearly half of complaints are not being independently investigated. This is compounded further by two factors. Firstly, even if GSOC does not have the resources to conduct more independent investigations it should be exercising its powers of supervision in the majority of cases, not the minority, as it is at present. Secondly, GSOC is looking for powers to 'lease back' less serious criminal matters to Garda investigation meaning that even more cases may be investigated by gardaí in the future [23].

The generally expressed concerns with police investigating police are firstly that police will not be willing or able to independently investigate fellow police officers and secondly, that even if they could/would, the public would not perceive this as independent. The former was abundantly clear in the Morris Tribunal: the officer assigned by the Complaints Board to investigate the complaints stated to the Tribunal that he simply did not believe that gardaí would do what was being alleged [35; para 12.104].

We would add two further concerns. Justice Morris expressed great dissatisfaction with the procedure applied for internal investigation of offences which empowered an 
investigating officer merely to take statements from those involved without permitting any questioning on those statements [35; para 10.26]. Of those cases received by GSOC but investigated by gardaí there is no indication that the procedure has been amended. The investigation of almost half of all admissible complaints submitted to GSOC is conducted by gardaí using an inadequate system, where the investigator is merely the taker of statements. In addition to this, the European Court of Human Rights has held that where a complaint concerns a breach of a Convention right an investigation by police officers will not be an effective remedy, and thereby a breach of the complainants rights. ${ }^{24} \mathrm{~A}$ 'lease-back' of less serious criminal matters for investigation by gardaí runs the risk of a failure to provide an effective remedy and Ireland falling foul of the Convention.

Other concerns can be expressed with the new system. Commissioners are appointed by the government, where an independent process would be preferred [23]. ${ }^{25}$ The current Commissioners are all children of gardaí which could have negative consequences for the perception of independence. Concerns also exist that the body will be under-resourced, like its predecessor, which was forced on occasion to close due to a lack of resources [49].

Many of the reforms of the complaints mechanism are commendable, and on paper this body has the potential to operate as a relatively independent complaints mechanism [11]. In practice however, it appears that too much emphasis has been placed on this mechanism to deliver Garda accountability [9]. As Vaughan [47; p.20] argues, in a holistic system the Ombudsman Commission would play a 'vital' role but it would be "much more minor than that envisaged in the debate on police accountability hitherto." It would also appear that it is not operating as the independent mechanism it is purported to be.

\section{The broader human rights context}

The reforms in the 2005 Act were complemented by a greater focus on the human rights agenda by Garda management. In 2002 a decision was taken to engage external

\footnotetext{
${ }^{24}$ Govell v. UK [1998] EHRLR 101; Khan v. UK [2000] 31 EHRR 1016.

${ }^{25}$ This re-emerged in the appointment of Dermot Gallagher, a senior civil servant, to the commission, following the death of its first chair, Mr Justice Kevin Haugh. See for instance Mark Kelly's letter to The Irish Times, 12 February 2009.
} 
consultants to conduct a human rights audit of the force. Their subsequent report provided a catalogue of human rights deficiencies across all aspects of Garda management and methods, and it detailed remedial measures that would need to be taken [51]. The Garda responded by preparing a plan to address the weaknesses. Commendably, both the report and the Garda plan were published.

Undoubtedly, there have been some human rights improvements in Garda governance and accountability consequent on this report and other recommendations for reform. We have already seen the new complaints procedure and the other reforms effected on foot of the 2005 Act. These have been complemented by a new disciplinary procedure [17] and a new whistle-blowing mechanism [16]. There has also been: a significant injection of civilianisation at senior management levels, the establishment of a human rights champion at Assistant Commissioner level, the establishment of a Human Rights Advisory Committee and the formation of a professional standards unit within the force [51]. These have been reinforced by a range of commitments on matters such as human rights proofing of operational policies, the incorporation of impact assessment protocols for Garda actions and improvements in Garda education and training programmes [51].

It is difficult to determine the extent to which many of these have translated into meaningful human rights advances in practice, or whether they are little more than paper exercises offering appearance over substance [51]. What is certain is that most of the consultants' recommendations on transparency have not been implemented. It is still the case, for example, that standing orders covering all aspects of Garda management and practices are not publicly accessible. The same applies to the existence and contents of Garda policies. Even with the creation of the Inspectorate and the Ombudsman Commission it remains difficult to access information which other jurisdictions take for granted as being within the public domain. One example is the operation of stop and search laws. While in the UK detailed information on when and why they are used is published, and is often the subject of academic research and study, no information on the use of this power is available for scrutiny in Ireland. For as long as such basic information is kept secret, transparent governance and accountability will remain elusive and the Garda will continue to be one of the most secretive police forces in the Western world. 


\section{Conclusion}

Undoubtedly the last five years has been a period of substantive Garda reform, both in terms of the legislative framework for police governance and accountability in Ireland and internal developments. The concern is however that Garda reform has had its moment, in the heat of the scandal, and as the Morris reports are relegated to recycling bins, so too is the impetus for change. There are a number of reasons why this is particularly worrying.

The Morris Tribunal was justifiably a real catalyst for change but it should not have been perceived as the sole basis for reform. That Tribunal was only examining one district and one particular set of cases. The full extent of misconduct in the Irish police has not been evaluated. Nor have we as a society engaged in discussions of what is expected of the Garda and what policing can realistically achieve. What is needed is an independent commission on policing; an initiative that all the major opposition parties have repeatedly supported.

There is still much in the reform proposals of the Morris Reports that have not been implemented. Indeed, most of the reform was implemented after just two reports had been published, and so the contents of the later reports have been largely ignored. Little has been done to address the cultural deficiencies in the Garda. For instance, Justice Morris identified a blue wall of silence in most of his reports. The response has been to implement a duty to account, a whistleblowers charter and to reinstate the keeping of officer's notebooks. These are procedural mechanisms which, while welcomed as necessary steps, will not engage in substantial cultural reform. As other jurisdictions have learned the difficult way, reform of culture takes continued training and education of all levels, an engendering of a new culture within management and supportive and reflective oversight [6]. Added to this must be a continuing awareness of changes in the society being policed which will impact on policing. Tick the box exercises cannot achieve this, particularly in the context of an Irish culture and society which economically has gone from boom to bust, where the ethnic make up is in fluctuation, where faith in institutions, long taken for granted, is disintegrating and where concepts of rights and democracy is flourishing. 
Other specific recommendations, such as the calls for a full implementation of the PEACE model of interrogation have been disregarded. The system is being revised, but not as Justice Morris advised. His recommendations on how the law of police surveillance should be developed were ignored in recent legislative reform of that area [10; p.161]. Recommendations on tenure of service and treatment of persons in custody have also been ignored. And no discussions have been held on the findings as regards abuse of detainees, which receive continual reinforcement by the findings of the ECPT.

Instead we have a Garda Síochána Act which focuses on centralisation of government control over the force which can only lead to politicisation and will not assist in improving the relationship between Garda Headquarters and the Department of Justice [50]. New accountability mechanisms were introduced but as we have argued these are not sufficiently independent and, in fact, run the risk of encouraging the public to believe they are independent.

As we emphasised in the introduction the broader context of any such reform must be examined closely to ensure balance between oversight and the powers being granted to the police. In the same period as these changes to accountability and governance have been made, a new 'war' has emerged in Ireland; a war on gangland crime, which the Minister has stated as being on a par with the seriousness of the Troubles. In 2009 alone six pieces of legislation were introduced which greatly expanded the powers of gardaí, in terms of surveillance, arrest and detention [8]. This has been done with minimal addition to safeguards and with concerns lingering over the extent to which human rights have been embedded in an Garda Síochána. Given that limitations have been placed on GSOC's work on the grounds of security of the State, and that the justification for many of these new powers is security of the State, recent reforms are unlikely to be relevant in this context.

Morris provided a very real opportunity to begin a realistic evaluation of policing in Ireland. Some of the new mechanisms such as the Inspectorate may have a lasting impact in this regard but we remain fearful that the chance to begin a long-term and effective reform process has been lost. Instead the police force has been brought more tightly under the control of the government. 


\section{$\underline{\text { Reference List }}$}

1. Allen, G. (1998). The Garda Síochána: Policing Independent Ireland 1922-1982.

Dublin: Gill \& MacMillan.

2. Barr, J. (2006). The Tribunal of Inquiry into the Facts and Circumstances Surrounding the Fatal Shooting of John Carthy at Abbeylara, Co. Longford on 20 April 2000. Dublin: The Stationery Office.

3. Birmingham, G. (2006). Report of the Commission of Investigation (Dean Lyons Case). Dublin: The Stationery Office.

4. Brady, C. (2000). Guardians of the Peace. Dublin: Gill and MacMillan.

5. Breathnach, S. (1974). The Irish Police: From Earliest Times to Present Day. Dublin: Anvil Press.

6. Chan, J. (1996). Changing Police Culture: Policing in a Multicultural Society. Cambridge: Cambridge University Press.

7. Conroy, J. (1970). Report on Remuneration and Conditions of Service. Dublin: The Stationary Office.

8. Conway, V., \& Mulqueen, M. (2009). The 2009 Anti-Gangland Package: Ireland's New Security Blanket? Irish Criminal Law Journal, 19(4),106-114.

9. Conway, V. (2009). A Sheep in Wolf's Clothing? Evaluating the Impact of the Garda Ombudsman Commission. Irish Jurist, XLIII, 109-130.

10. Conway, V. (2010) The Blue Wall of Silence: The Morris Tribunal and Police Accountability in Ireland. Dublin: Irish Academic Press.

11. Conway, V., Daly, Y., \& Schweppe, J. (2010). Irish Criminal Justice: Theory, Process and Procedure. Dublin: Clarus Press.

12. Dixon, D. and Chan, J. (2007) The Politics of Police Reform: Ten Years After the Royal Commission into the New South Wales Police Service. Criminology and Criminal Justice, 7(4), 443-468.

13. Fitzgerald, T.P. (2008). The Morris Tribunal and an Garda Síochána. Communique, March, 3-36.

14. Garda Síochána Act 2005. Dublin: The Stationary Office.

15. Garda Síochána Complaints Board.(2002). Annual Report 2002. Dublin. 
16. Garda Síochána (Confidential Reporting of Corruption or Malpractice) Regulations 2007. Dublin: The Stationary Office

17. Garda Síochána (Discipline) Regulations 2007. Dublin: The Stationary Office.

18. Garda Síochána Ombudsman Commission. (2008). Annual Report 2008. Dublin.6

19. Garda Síochána Ombudsman Commission. (2009). Annual Report 2009. Dublin.

20. Garda Síochána Ombudsman Commission. (2008). Biannual Report on Effectiveness of the Ombudsman Commission. Dublin.

21. Hartnett, H. (2008). Inquiry Pursuant to the Dublin Police Act 1924 as Amended by the Police Force Amalgamation Act 1925. Dublin: The Stationary Office.

22. Herlihy, J. (1999). The Dublin Metropolitan Police: A Short History and Genealogical Guide. Dublin: Four Courts Press.

23. Irish Human Rights Commission. (2004). Observations on the Garda Siochána Bill. Dublin.

24. Lowe, W.J. (2002). The War Against the RIC 1919-1921. Eire:Ireland: A Journal of Irish Studies, 37(3), 79-117.

25. Lynch, K. (1985). Report of the Tribunal of Inquiry into "the Kerry Babies Case”. Dublin: Stationary Office.

26. McCullagh, C. (2005). The Global in the Local: Police Corruption in Donegal. Unpublished.

27. McGarry, F. (2007). Eoin O’Duffy: a Self-Made Hero. Oxford: Oxford University Press.

28. McNiffe, L. (1997). A History of an Garda Síochána. Dublin: Merlin Publishing.

29. Morris, F. (2004). Report of the Tribunal Set up Pursuant to the Tribunal of Inquiry (Evidence) Acts 1921-2003 into Certain Gardai in the Donegal Division: Term of Reference (e) Report on Explosives 'Finds' in Donegal. Dublin: The Stationary Office.

30. Morris, F. (2005). Report of the Tribunal Set up Pursuant to the Tribunal of Inquiry (Evidence) Acts 1921-2003 into Certain Gardai in the Donegal Division: Terms of Reference (a) and (b); Report of the Investigation into the Death of Richard Barron and the Extortion Calls to Michael and Charlotte Peoples. Dublin: The Stationary Office.

31. Morris, F. (2006). Report of the Tribunal Set up Pursuant to the Tribunal of Inquiry (Evidence) Acts 1921-2003 into Certain Gardai in the Donegal Division: Term of Reference (i) Report on the Arrest and Detention of Seven Persons at Burnfoot, Co. 
Donegal on $23^{\text {rd }}$ May 1998 and the Investigation Relating to Same. Dublin: The Stationary Office.

32. Morris, F. (2006). Report of the Tribunal Set up Pursuant to the Tribunal of Inquiry (Evidence) Acts 1921-2003 into Certain Gardai in the Donegal Division: Term of Reference (g): Report on the Garda Investigation of an Arson Attack on Property Situated on the Site of the Telecommunications Mast at Ardara, Co Doneal in October and November 1996. Dublin: The Stationary Office.

33. Morris, F. (2008). Report of the Tribunal Set up Pursuant to the Tribunal of Inquiry (Evidence) Acts 1921-2003 into Certain Gardai in the Donegal Division: Terms of Reference (b), (d) and (f): Report on the Detention of 'Suspects' Following the Death of the late Richard Barron on $14^{\text {th }}$ October 1996 and Related Detentions and Issues. Dublin: The Stationary Office.

34. Morris, F. (2008). Report of the Tribunal Set up Pursuant to the Tribunal of Inquiry (Evidence) Acts 1921-2003 into Certain Gardai in the Donegal Division: Term of Reference (c): Report on Allegations of Harassment of the McBrearty Family in Raphoe. Dublin: The Stationary Office.

35. Morris, F. (2008). Report of the Tribunal Set up Pursuant to the Tribunal of Inquiry (Evidence) Acts 1921-2003 into Certain Gardai in the Donegal Division: Term of Reference (j) Report into the Effectiveness of the Garda Siochána Complaints Board Inquiry. Dublin: The Stationary Office.

36. Newburn, T. (1999). Understanding and Preventing Police Corruption: Lessons from the Literature. London: HMSO, Police Research Series Paper 110.

37. O’Rawe, M., \& Moore, L. (1997). Human Rights on Duty: Principles for Better Policing - Lessons from Northern Ireland. Belfast: Committee on the Administration of Justice.

38. Patten, C. (1999). Policing: A New Beginning for Northern Ireland. London: HMSO.

39. Punch, M. (1985). Conduct Unbecoming : The Social Construction of Police Deviance and Control. London: Tavistock .

40. Punch, M. (2009). Police Corruption: Deviance, Accountability and Police Reform. Cullumpton: Willan

41. Savage, S. (1997). Police Reform: Forces for Change. Oxford: Oxford University Press.

42. Scraton, P. (1985). The Police State We Are In. London: Pluto Press.

43. Sherman, L. (1978). Scandal and Reform: Controlling Police Corruption. California: University of California Press. 
44. Stenning, P., \& Shearing, C. (2005). Reforming Police: Opportunities, Drivers and Challenges. Australian and New Zealand Journal of Criminology, 38(2),167 -180.

45. Stoddard, E. (1968). The Informal Code of Police Deviance: A Group Approach to "Blue Coat Crime". Journal of Criminal Law, Criminology and Police Science, 59(2), 201-213.

46. Use of Electronic Recording of Interviews Regulations 1997. Dublin: The Stationary Office.

47. Vaughan, B. (2005). A New System of Police Accountability: The Garda Síochána Act 2005. Irish Criminal Law Journal, 15(3), 18-24.

48. Walsh, D.P.J. (1998). The Irish Police: A Legal and Constitutional Perspective. Dublin: Butterworths.

49. Walsh, D.P.J. (2009). Twenty Years of Police Complaints in Ireland: A Critical Assessment of the Review Board Model. Legal Studies, 29(2), 305-338.

50. Walsh, Dermot, P.J. (2009). Tightening the noose of central government control over policing in Ireland: innovations in the Garda Síochána Act 2005. Northern Ireland Legal Quarterly, 60(2), 163-180.

51. Walsh, D.P.J. (2009). Human Rights and Policing in Ireland: Law, Policy and Practice. Dublin: Clarus Press. 